Article

\title{
Antibiotic Resistance and Virulence Traits in Vancomycin-Resistant Enterococci (VRE) and Extended-Spectrum $\beta$-Lactamase/AmpC-producing (ESBL/AmpC) Enterobacteriaceae from Humans and Pets
}

\author{
Ramona Iseppi $^{1, *,+(\mathbb{D})}$, Alessandro Di Cerbo ${ }^{2, *,+} \mathbb{D}$, Patrizia Messi ${ }^{1} \mathbb{D}$ and Carla Sabia ${ }^{1}(\mathbb{D})$ \\ 1 Department of Life Sciences, University of Modena and Reggio Emilia, Via G. Campi 287, \\ 41125 Modena, Italy; patrizia.messi@unimore.it (P.M.); carla.sabia@unimore.it (C.S.) \\ 2 School of Biosciences and Veterinary Medicine, University of Camerino, Via Circonvallazione 93/95, \\ 62024 Matelica, Italy \\ * Correspondence: ramona.iseppi@unimore.it (R.I.); alessandro.dicerbo@unicam.it (A.D.C.); \\ Tel.: +39-059-2055795 (R.I.); +39-0737-403443 (A.D.C.) \\ + These authors contributed equally.
}

Received: 11 March 2020; Accepted: 30 March 2020; Published: 31 March 2020

check for updates

\begin{abstract}
Background: We investigated the virulence factors, genes, antibiotic resistance patterns, and genotypes (VRE and ESBL/AmpC) production in Enterococci and Enterobacteriaceae strains isolated from fecal samples of humans, dogs, and cats. Methods: A total of 100 fecal samples from 50 humans, 25 dogs, and 25 cats were used in the study. MICs of nine antimicrobials were determined using the broth microdilution method. Polymerase chain reaction was used for the detection of genes responsible for antibiotic resistance (VRE and ESBL/AmpC) and virulence genes both in Enterococcus species, such as cytolysin (cylA, cylB, cylM), aggregation substance (agg), gelatinase (gelE), enterococcal surface protein (esp), cell wall adhesins (efaAfs and efaAfm), and in Enterobacteriaceae, such as cytolysin (hemolysin) and gelatinase production (afa, cdt, cnf1, hlyA, iutA, papC, sfa). Results: Enterococcus faecium was the most prevalent species in humans and cats, whereas Enterococcus faecalis was the species isolated in the remaining samples. A total of 200 Enterobacteriaceae strains were also detected, mainly from humans, and Escherichia coli was the most frequently isolated species in all types of samples. In the Enterococcus spp, the highest percentages of resistance for ampicillin, amoxicillin/clavulanate, erythromycin, tetracycline, ciprofloxacin, teicoplanin, and vancomycin were detected in cat isolates $(41.6 \%, 52.8 \%, 38.9 \%, 23.6 \%, 62.5 \%, 20.8 \%$, and $23.6 \%$ respectively), and in E. coli, a higher rate of resistance to cefotaxime and ceftazidime emerged in cat and dog samples, if compared with humans $(75.4 \%$ and $66.0 \%, 80.0 \%$ and $71.4 \%$, and $32.0 \%$ and $27.2 \%$, respectively). Regarding the total number of enterococci, $5 \%$ and $3.4 \%$ of the strains were vancomycin and teicoplanin resistant, and the vancomycin resistance (van A) gene has been detected in all samples by PCR amplification. All the Enterobacteriaceae strains were confirmed as ESBL producers by PCR and sequencing, and the most frequent ESBL genes in E. coli strains from humans and pet samples were $b l a_{\mathrm{CTX}-\mathrm{M}-1}$ and $b l a_{\mathrm{CTX}-\mathrm{M}-15}$. Conclusions: Our results provide evidence that one or more virulence factors were present in both genera, underlining again the ability of pet strains to act as pathogens.
\end{abstract}

Keywords: virulence factors; VRE; ESBL; humans; dogs; cats 


\section{Introduction}

Antimicrobial resistance (AMR) is a major health problem rapidly spreading across the world [1], and the interest of the scientific community in the presence and circulation of resistant organisms between pets and humans has also increased due to the important public health implications. Enterococcus spp. and Enterobacteriaceae represent important human and veterinary pathogens/opportunists and a significant burden for healthcare systems worldwide. The presence of these bacterial species in the gastrointestinal tract of both species plays a role in maintaining the normal digestive and immune functions of the hosts [2,3]. In addition, these bacteria species have also been found to participate in metabolic activities that save energy and absorbable nutrients as well as protect the colonized host against invasion by foreign microbes [4].

Although these microorganisms are commensal in the gut of most animals and common in environments contaminated by human and animal feces, they emerged as nosocomial and community-acquired pathogens for their ability to develop high-level resistance to antimicrobials [5]. Enterococci are common hospital-acquired pathogens, accounting for $9.6 \%$ of all healthcare-associated infections in European countries [6], but knowledge about their epidemiology is still unclear and the possible zoonotic spread of antimicrobial-resistant enterococci is controversial. Studies on the virulence factors of Enterococcus strains such as cytolysin, aggregation substance (AS), gelatinase, antibiotic susceptibility, and genetic heterogeneity showed differences among the strains according to their host origins [7-9].

The introduction of cefotaxime and, generally, the third-generation cephalosporins was a milestone in antimicrobial chemotherapy. As a result of selective pressure exerted by these new cephalosporins, resistance in enterobacterial species emerged a few years later [10]. Extended-spectrum- $\beta$-lactamase (ESBL) and plasmid mediated (p)AmpC-producing Enterobacteriaceae have been isolated from humans, different animal species, and environments worldswide. ESBL/AmpC producing Enterobacteriaceae in humans and animals have also been increasingly reported [11,12]. Despite many studies on ESBL/AmpC-producing bacteria from different sources, clear data, especially on routes of transmission, are still lacking and, consequently, the epidemiology of ESBL/pAmpCs is also poorly understood. One of the driving forces behind the increased resistance is the use of third and fourth generation cephalosporins in humans and animals [13]. The European Medicines Agency recommends the use of these antimicrobials only when there are no other alternative authorized antimicrobials for the respective target species and indications [14]. In companion animals, among others, the first-generation cephalosporin cephalexin and third-generation, long-acting cephalosporin cefovecin are commonly used and licensed in Europe. Several studies have reported the presence of ESBL/pAmpC-producing Enterobacteriaceae in clinical samples from companion animals [15-17]; however, knowledge about the intestinal carriage of ESBL/AmpCs in healthy companion animals is limited $[18,19]$.

Given that companion animals have been suggested as potential reservoirs for antimicrobial-resistant bacteria $[18,20]$, we studied the circulation of resistant bacteria in pets to obtain a deeper knowledge on the possible role in transmission to humans. For this purpose, we investigated virulence factors, genes, antibiotic resistance patterns, and genotypes (VRE and ESBL/AmpC) production in Enterococcus and Enterobacteriaceae strains isolated from fecal samples of humans, dogs, and cats.

\section{Results}

\subsection{Isolation and Identification of Bacterial Strains}

A total of 200 enterococcal isolates were recovered from 100 fecal samples of humans, dogs, and cats. The preliminary identification of the isolates to species level by biochemical tests was confirmed by PCR results in all the isolates. Table 1 shows the distribution of enterococcal species in samples of different origin. 
Table 1. Number (\%) of isolates of Enterococcus and Enterobacteriaceae from 100 fecal samples of humans, cats, and dogs.

\begin{tabular}{cccc}
\hline Enterococcusspecies & Humans $(\boldsymbol{n = 8 0 )}$ & Cats (72) & Dogs (48) \\
\hline E. faecium & $68(80)$ & $52(72.2)$ & $24(50)$ \\
E. faecalis & $12(1.5)$ & $20(27.7)$ & $24(50)$ \\
\hline Enterobacteriaceae & Humans $(n=110)$ & Cats (55) & Dogs (35) \\
species & $103(93.6)$ & $53(96.3)$ & $25(71.4)$ \\
\hline E. coli & $4(3.8)$ & $2(36.3)$ & $10(28.5)$ \\
C. freundii & $3(2.7)$ & 0 & 0 \\
K. pneumoniae & &
\end{tabular}

Enterococcus faecium was the most prevalent species in humans, cats and dogs $(80 \%, 72.2 \%$ and $50 \%$ respectively), and Enterococcus faecalis was the only species isolated in the remaining samples ( $1.7 \%$ in humans, $27.7 \%$ in cats and $50 \%$ in dogs). No difference in the percentage of recovery between the two enterococcal species has emerged in dog isolates. A total of 200 Enterobacteriaceae strains were also detected; 110 from humans, 55 from cats, and 35 from dogs (Table 1). Escherichia coli was found to be the most isolated species in all types of samples $(93.6 \%, 96.3 \%$, and $71.4 \%$ in humans, cats, and dogs, respectively), followed by Citrobacter freundii (3.8\%, 36.3\%, and $28.5 \%$ in humans, cats, and dogs, respectively). Lastly, three Klebsiella pneumoniae strains (2.7\%) were recovered in human samples only.

\subsection{Antimicrobial Susceptibility Test}

Table 2 shows the levels of antimicrobial resistance detected in enterococcal isolates, according to isolated species.

Table 2. Percentages of antimicrobial resistance in enterococci isolated from fecal samples of humans, cats, and dogs.

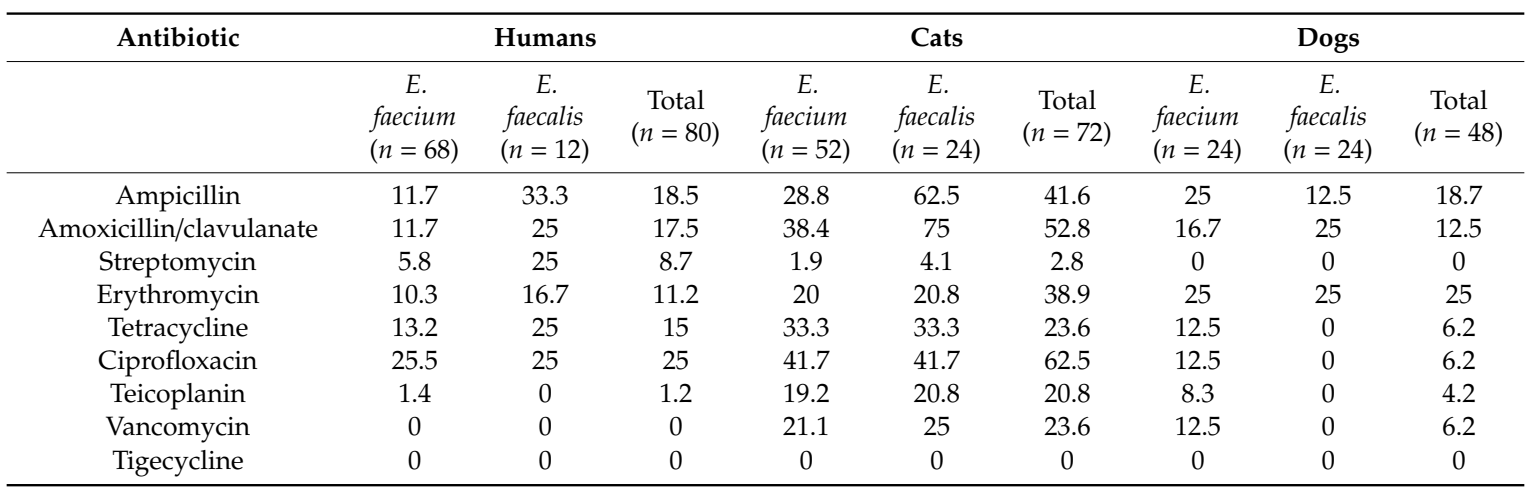

The highest percentages of resistance for ampicillin, amoxicillin/clavulanate, erythromycin, tetracycline, ciprofloxacin, teicoplanin, and vancomycin were detected in cat isolates $(41.6 \%, 52.8 \%$, $38.9 \%, 23.6 \%, 62.5 \%, 20.8 \%$, and $23.6 \%$ respectively), compared with human isolates $(18.5 \%, 17.5 \%$, $8.7 \%, 11.2 \%, 15 \%, 25 \%$, and $1.2 \%$, respectively); intermediate levels of resistance to these antibiotics were observed in dog isolates $(18.7 \%, 12.5 \%, 25 \%, 6.2 \%, 6.2 \%, 4.2 \%$, and $6.2 \%$, respectively) (Table 2). With respect to streptomycin, a higher percentage of resistance in human isolates (8.7\%) than in those of dogs $(2.8 \%)$ and cats $(0 \%)$ was observed. All the strains resulted sensitive to Tigecycline. Fisher's exact test conducted on each antibiotic resistance percentages found in E. faecium and E. faecalis for each species revealed no statistical significance, confirming the almost absolute independendent occorrunce of the resistance percentages from the operator's action. The only exceptions were represented by cat ampicillin $\left({ }^{*} p<0.05\right)$ and amoxicillin/clavulanate $\left({ }^{*} p<0.01\right)$ resistance percentages, possibly indicating a bias due to the operator. 
Table 3 shows the percentage of antibiotic susceptibility pattern in E. coli and C. freundii strains, which are the two most frequently isolated Enterobacteriaceae species from samples of different origins, and in K. pneumoniae spp., which was recovered from human samples only.

Table 3. Percentages of antimicrobial resistance in Enterobacteriaceae isolated from fecal samples of humans, cats, and dogs.

\begin{tabular}{|c|c|c|c|c|c|c|c|c|c|}
\hline \multirow[t]{2}{*}{ Antibiotic } & \multicolumn{3}{|c|}{ Humans } & \multicolumn{3}{|c|}{ Cats } & \multicolumn{3}{|c|}{ Dogs } \\
\hline & $\begin{array}{c}\text { E. coli } \\
(n=103)\end{array}$ & $\begin{array}{c}C . \\
\text { freundii } \\
(n=4)\end{array}$ & $\begin{array}{c}\text { K. } \\
\text { pneumoniae } \\
(n=3)\end{array}$ & $\begin{array}{c}\text { E. coli } \\
(n=53)\end{array}$ & $\begin{array}{c}C . \\
\text { freundii } \\
(n=2)\end{array}$ & $\begin{array}{c}\text { K. } \\
\text { pneumoniae } \\
(n=0)\end{array}$ & $\begin{array}{c}\text { E. coli } \\
(n=35)\end{array}$ & $\begin{array}{c}C . \\
\text { freundii } \\
(n=10)\end{array}$ & $\begin{array}{c}\text { K. pneumoniae } \\
(n=0)\end{array}$ \\
\hline Ampicillin & 79.7 & 100 & 100 & 86.7 & 50 & 0 & 85.7 & 100 & 0 \\
\hline Amoxicillin/clavulanate & 77.6 & 100 & 100 & 86.7 & 50 & 0 & 85.7 & 100 & 0 \\
\hline Cefotaxime & 32 & 75 & 100 & 75.4 & 100 & 0 & 80 & 50 & 0 \\
\hline Ceftazidime & 27.2 & 75 & 100 & 66 & 50 & 0 & 71.4 & 50 & 0 \\
\hline Ciprofloxacin & 19.4 & 0 & 0 & 28.3 & 0 & 0 & 0 & 0 & 0 \\
\hline Imipenem & 0 & 0 & 0 & 0 & 0 & 0 & 0 & 0 & 0 \\
\hline Meropenem & 0 & 0 & 0 & 0 & 0 & 0 & 0 & 0 & 0 \\
\hline
\end{tabular}

All three species were sensitive to meropenem and imipenem. A high percentage of resistance, up to $100 \%$, was in general observed for ampicillin and amoxicillin-clavulanic acid, except for $C$. freundii of cat origin (50\%). A high rate of resistance to cefotaxime and ceftazidime was noticed in C. freundii and K. pneumonia strains of human origin and for cefotaxime in C. freundii isolated from cat. An intermediate level of resistance to cefotaxime was both observed in C. freundii from cat (50\%) and dog isolates $(50 \%)$, the latter also having a reduced sensitivity to ceftazidime. With regard to $E$. coli, a high percentage of resistance to cefotaxime and ceftazidime emerged in cat and dog samples, if compared with humans. Lastly, a higher rate of resistance to tetracycline was observed in E. coli of cat origin $(52.8 \%)$, rather than in human and dog isolates $(9.71 \%$ and $0 \%$, respectively). It was interesting that E. coli and C. freundii from all species had multiresistance to ampicillin, amoxicillin/clavulanate, cefotaxime, ceftazidime, and cefepime, while only K. pneumonie from humans had multiresistance to the aforementioned antibiotics. As for cats and humans, an intriguing multiresistance to tetracycline and ciprofloxacin was observed in E. coli. A Chi-square test for trend conducted on each antibiotic resistance percentage found in E. coli, C. freundii, and K. pneumoniae of humans revealed a statistical significance only for cefotaxime $\left({ }^{* *} p<0.01\right)$ and ceftazidime $\left({ }^{* *} p<0.001\right)$, possibly indicating a bias due to the operator. Coversely, Fisher's exact test conducted on each antibiotic resistance percentage found in E. coli, C. freundii, and K. pneumoniae of pets revealed no statistical significance, confirming the absolute independendent occorrunce of the resistance percentages from the operator's action.

\subsection{Detection of Van Genes}

On the total number of isolates, $10 \%$ and $9 \%$ of the strains were vancomycin and teicoplanin resistant (Tables 2 and 3). The highest rate of resistance was observed in both E. faecium and E. faecalis strains from cats $(19.2 \%$ and $20.8 \%$ for teicoplanin and $21.1 \%$ and $25 \%$ for vancomycin, respectively). Resistance to the same antibiotics was also detected in dog samples, but this was mainly related to E. faecium species (8.3 and 12.5 for teicoplanin and vancomycin, respectively). With regard to human samples, one E. faecium isolate only was insensitive to teicoplanin. Lastly, vancomycin resistance genes (van A) have been detected in all samples by PCR amplification.

\subsection{Detection and Sequencing of Extended Spectrum Lactamase and AmpC Genes}

Almost all isolates carried at least one ESBL/AmpC gene (Table 4). All the strains, 83.6\% isolated from humans, $88.6 \%$ from dogs, and $43.6 \%$ from cat, were confirmed as ESBL producers by PCR and sequencing. In particular, the ESBL-producing strains isolated from humans belonged to the following genes (species/number of isolates): bla $a_{\mathrm{TEM}-92}, b l a_{\mathrm{TEM}-20}$, and $b l a_{\mathrm{TEM}-52}$ (E. coli/20, 8, and 10, respectively), bla $a_{\mathrm{CTX}-\mathrm{M}-1}$ (E. coli/18, K. pneumoniae/8), and bla ${ }_{\mathrm{CTX}-\mathrm{M}-15}$ (E. coli/30, C. freundii/2). Among cat and dog 
isolates, the $b l a_{\mathrm{TEM}-52}$ and $b l a_{\mathrm{CTX}-\mathrm{M}-1}$ were carried by E. coli/2 and 5, E. coli/8 and E. coli/9 respectively. Lastly, bla $a_{\mathrm{CTX}-\mathrm{M}-15}$ was recovered in both cat and dog isolates (E. coli/11 and C. freundii/1 in cat isolates;

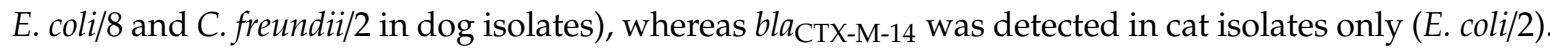

Table 4. Distribution of $\beta$-lactamase genes (\%) in Enterobacteriaceae isolates of human cat and dog isolates.

\begin{tabular}{|c|c|c|c|c|c|c|c|c|c|}
\hline \multirow{2}{*}{$\begin{array}{c}\text { Source } \\
\mathbf{N}^{\circ} \text {. of Isolate }{ }^{a}\end{array}$} & \multicolumn{3}{|c|}{ Humans } & \multicolumn{3}{|c|}{ Cats } & \multicolumn{3}{|c|}{ Dogs } \\
\hline & $\begin{array}{c}\text { E. coli } \\
(n=103)\end{array}$ & $\begin{array}{c}C . \\
\text { freundii } \\
(n=4)\end{array}$ & $\begin{array}{c}\text { K. } \\
\text { pneumoniae } \\
(n=3)\end{array}$ & $\begin{array}{c}\text { E. coli } \\
(n=53)\end{array}$ & $\begin{array}{c}C . \\
\text { freundii } \\
(n=2)\end{array}$ & $\begin{array}{c}\text { K. } \\
\text { pneumoniae } \\
(n=0)\end{array}$ & $\begin{array}{c}\text { E. coli } \\
(n=25)\end{array}$ & $\begin{array}{c}C . \\
\text { freundii } \\
(n=10)\end{array}$ & $\begin{array}{c}\text { K. } \\
\text { pneumoniae } \\
(n=0)\end{array}$ \\
\hline \multicolumn{10}{|l|}{ Penicillinases $^{b}$} \\
\hline$b l a_{\mathrm{TEM}-1}$ & $14.5(15)$ & $50(2)$ & $33.3(1)$ & $60(30)$ & $50(1)$ & 0 & $40(10)$ & $40(4)$ & 0 \\
\hline ESBL $^{b}$ & & & & & & 0 & & & 0 \\
\hline$b l a_{\mathrm{TEM}-52}$ & $9.7(10)$ & 0 & 0 & $3.7(2)$ & 0 & 0 & $20(5)$ & 0 & 0 \\
\hline$b l a_{\mathrm{CTX}-\mathrm{M}-1}$ & $17.4(18)$ & 0 & $66.7(2)$ & $22.5(8)$ & 0 & 0 & $36(9)$ & 0 & 0 \\
\hline bla $a_{\mathrm{CTX}-\mathrm{M}-14}$ & 0 & 0 & 0 & 0 & 0 & 0 & $8(2)$ & 0 & 0 \\
\hline$b l a_{\mathrm{CTX}}-\mathrm{M}-15$ & $29.1(30)$ & $50(2)$ & 0 & $20.7(11)$ & $50(1)$ & 0 & $32(8)$ & $60(6)$ & 0 \\
\hline $\mathrm{AmpC}^{\mathrm{b}}$ & & & & 0 & & & 0 & 0 & \\
\hline$b l a_{\mathrm{MIR}-1}$ & $19.4(2)$ & & & 0 & & & 0 & 0 & 0 \\
\hline
\end{tabular}

${ }^{a}$ Numerous isolates encoded for more than one $\beta$-lactamase gene. ${ }^{\mathbf{b}} \%$ of $\beta$-lactamase genes ( ${ }^{\circ}$. of isolates).

Non-ESBL gene $b l a_{\mathrm{TEM}-1}$ was the most frequently identified $\beta$-lactamase gene among all the isolates. It was detected in $16.3 \%$ of the human isolates and in $56.3 \%$ and $40 \%$ of cat and dog isolates.

The AmpC gene bla $a_{\mathrm{MIR}-1}$ was detected in two human isolates (E. coli), while two cat and one dog isolates E. coli harbored the gene bla $a_{\mathrm{CMY}-2}$ (Table 4).

\subsection{Detection of Virulence Factors in Enterococcus Species}

The distribution of the virulence factors and genes in Enterococcus species by their origins are given in Table 5.

Table 5. Distribution of virulence factors and genes among E. faecalis and E. faecium isolates: cytolysin (cylA, cylB, cylM), aggregation substance (agg), gelatinase (gelE), enterococcal surface protein (esp), and cell wall adhesins (efaAfs and efaAfm).

\begin{tabular}{ccccc}
\hline Virulence Factors/Genes & Human $\boldsymbol{n = 8 0 ( \% )}$ & Cat $\boldsymbol{n}=\mathbf{7 2}(\mathbf{\%})$ & Dog $\boldsymbol{n}=\mathbf{4 8}(\mathbf{\%})$ & Total $\boldsymbol{n}=\mathbf{2 0 0}(\mathbf{\%})$ \\
\hline Gelatinase & $25(31.2)$ & $16(22.2)$ & $8(16.6)$ & $49(24.5)$ \\
$*$ AS & $9(11.2)$ & $2(2.7)$ & 0 & $11(5.5)$ \\
Cytolysin & $5(6.2)$ & 0 & 0 & $5(2.5)$ \\
gelE & $27(33.7)$ & $10(13.9)$ & $2(4.1)$ & $39(19.5)$ \\
cylA & $3(3.7)$ & 0 & 0 & $3(1.5)$ \\
cylB & $3(3.7)$ & 0 & 0 & $3(1.5)$ \\
cylM & $6(7.5)$ & $3(4.1)$ & $1(2)$ & $10(5)$ \\
agg & $8(10)$ & $3(4.1)$ & 0 & $11(5.5)$ \\
esp & $10(12.5)$ & 0 & 0 & $10(20)$ \\
efaAfs & $21(26.2)$ & $9(12.5)$ & $8(16.6)$ & $38(19)$ \\
efaAfm & $12(15)$ & $8(11.1)$ & $8(16.6)$ & $28(14)$ \\
\hline
\end{tabular}

* aggregation substance.

Gelatinase and gelE were detected in $31.2 \%$ and $33.7 \%$, in $22.2 \%$ and $13.9 \%$, and in $16.6 \%$ and $4.1 \%$ of human, cat, and dog isolates, respectively. With regard to AS, encoded by agg., it was detected in $11.2 \%$ and $10 \%$ of human isolates and in $2.7 \%$ and $0 \%$ of cat isolates, respectively. The lack of AS and agg. gene in dog isolates suggests a low virulence and a reduced capability of the strains to show virulence traits. The absence of cytolysin and its respective genes (cylA, cylB) was observed in cat and dog isolates, as opposed to human ones (6.2\%), while the cylM gene was detected in $7.5 \%, 4.1 \%$, and 
$2 \%$ of human, cat, and dog isolates, respectively. The esp gene was present but with low prevalence $(12.5 \%)$ in human isolates only. Lastly, the efaAfs and efaAfm genes were found in $26.2 \%, 12.5 \%$, and $16.6 \%$, and in $15 \%, 11.1 \%$, and $16.6 \%$ of human, cat, and dog isolates, respectively.

\subsection{Detection of Virulence Factors in Enterobacteriaceae}

The distribution of the virulence factors and genes in Enterobacteriaceae by their origins are given in Table 3B. Gelatinase and cytolysin were detected in E. coli species only, in $27.2 \%$ and $8.7 \%$, in $30.2 \%$ and $3.7 \%$, and in $32 \%$ and $0 \%$, of human, cat, and dog isolates, respectively.

The detection of virulence factors using PCR revealed that $95(47.5 \%)$ of all strains $(n=200)$ were positive for at least one of the virulence genes tested (except for the cdt gene); of these strains, 53 $(56.7 \%)$ were humans, $19(34.5 \%)$ were cats, and 24 (68.5\%) were dogs. In the strains isolated from humans, afa, cnf1, hlyA, iutA, papC, and sfa were the most common virulence genes identified in E. coli $(0.9 \%, 11.6 \%, 5.8 \%, 5.8 \%, 14.5 \%$, and $9.7 \%$, respectively), followed by papC in C. freundii $(50 \%)$ and in K. pneumoniae (18.8\%). In cat and dog strains, hlyA $(2 \%, 3 \%)$, iutA $(4 \%, 8 \%)$, papC $(10 \%, 5 \%)$, and sfa ( $2 \%$ and $8 \%)$ were the most common virulence genes, present only in E.coli. Lastly, cdt genes have never been detected in any species (Table 6).

Table 6. Frequency of virulence factors and genes (\%) among faecal E. coli, C. freundii, and K. pneumoniae isolated from human, cat, and dog samples.

\begin{tabular}{|c|c|c|c|c|c|c|c|c|c|c|}
\hline \multirow[t]{2}{*}{$\begin{array}{c}\text { Virulence } \\
\text { Factors/Genes }\end{array}$} & \multicolumn{3}{|c|}{ Humans } & \multicolumn{3}{|c|}{ Cats } & \multicolumn{3}{|c|}{ Dogs } & \multirow[t]{2}{*}{ Total $n=200(\%)$} \\
\hline & $\begin{array}{c}\text { E. coli } \\
(n=103)\end{array}$ & $\begin{array}{c}C . \\
\text { freundii } \\
(n=4)\end{array}$ & $\begin{array}{c}\text { K. } \\
\text { pneumoniae } \\
(n=3)\end{array}$ & $\begin{array}{c}\text { E. coli } \\
(n=53)\end{array}$ & $\begin{array}{c}C . \\
\text { freundii } \\
(n=2)\end{array}$ & $\begin{array}{c}\text { K. } \\
\text { pneumoniae } \\
(n=0)\end{array}$ & $\begin{array}{c}\text { E. coli } \\
(n=35)\end{array}$ & $\begin{array}{l}\text { C. freudii } \\
(n=10)\end{array}$ & $\begin{array}{c}\text { K. } \\
\text { pneumoniae } \\
(n=0)\end{array}$ & \\
\hline Gelatinase & $25(27.2)$ & 0 & 0 & $16(30.2)$ & 0 & 0 & $8(32)$ & 0 & 0 & $49(24.5)$ \\
\hline Cytolysin & (8.7) & 0 & 0 & $2(3.7)$ & 0 & 0 & 0 & 0 & 0 & $11(5.5)$ \\
\hline afa & $1(0.9)$ & 0 & 0 & 0 & 0 & 0 & 0 & 0 & 0 & $1(0.5)$ \\
\hline $\mathrm{cdt}$ & 0 & 0 & 0 & 0 & 0 & 0 & 0 & 0 & 0 & 0 \\
\hline cnf1 & 12 (11.6) & 0 & 0 & 0 & 0 & 0 & 0 & & 0 & $12(6)$ \\
\hline hlyA & $6(5.8)$ & 0 & 0 & $2(3.7)$ & 0 & 0 & $3(12)$ & 0 & 0 & $11(5.5)$ \\
\hline iutA & $6(5.8)$ & 0 & 0 & $4(7.5)$ & 0 & 0 & $8(32)$ & 0 & 0 & $18(9)$ \\
\hline papC & 15 (14.5) & $2(50)$ & $1(33.3)$ & $10(18.8)$ & 0 & 0 & $5(20)$ & 0 & 0 & 33 (16.5) \\
\hline sfa & $10(9.7)$ & 0 & 0 & $2(3.7)$ & 0 & 0 & $8(32)$ & 0 & 0 & $20(10)$ \\
\hline
\end{tabular}

\section{Discussion}

This study investigated the antibiotic resistance and virulence traits in enterococci and Enterobacteriaceae isolated from faeces of humans, dogs, and cats.

It is interesting to underline the low prevalence of E. faecalis, the most frequent enterococcal species detected in human infections [21,22] and fecal isolates, compared with E. faecium. Nevertheless, E. faecalis was the predominant enterococcal species in our fecal dog samples, similar to other studies [23,24].

Enterococci are commensal bacteria that possess natural gene transfer mechanisms that are able to spread multiple resistances. Therefore, it becomes crucial to study and characterize the strains isolated from household animals [25]. The enterococci isolated from pets possessed the highest rate of resistance to teicoplanin and vancomycin, whereas only one E. faecium of human source was insensitive to teicoplanin. Simjee et al. suggested that vancomycin-resistant enterococci may be acquired by humans through contact with dogs [26], which is a hypothesis that is also supported by Leener et al., who reported vancomycin resistance rates in pets higher than ours [27]. The presence in pets of enterococcus isolates with other biological traits such as gelatinase, aggregation substance, cytolysin, and the presence of their respective virulence genes (gelE, aggesp, cylA, cylB, cylM, efaAfsand, efaAfm) emphasizes the pathogenicity of these strains. The incidence of cytolysin in our study was lower than that previously reported by some researchers [28,29]. In total, the gelE gene was detected in $19.5 \%$ of all isolates and was the most common factor, as reported in other studies $[28,30,31]$. The esp was the less frequently detected virulence gene in dog and cat isolates, compared to human ones, which is a result that is consistent with previous reports [32-36]. Lastly, a lower percentage of strains producing hemolysin, gelatinase and AS emerged, when compared with the genotypic characterization. This 
may be due to the presence of silent and undetected genes or to the detection of a single gene inside an operon, which was obtained by PCR analysis. The conflicting results of our study versus other investigations concerning the occurrence of virulence factors among isolates might also be due to differences in the ecological origin of strains or to the sensitivity of different detection methods.

With regard to the identification of the Enterobacteriaceae strains, Escherichia coli was found to be the most frequently isolated species from all types of samples, followed by Citrobacter freundii, whereas Klebsiella pneumoniae was recovered in human samples only (three strains). The antibiotic resistance patterns of our isolates showed a high percentage of resistance to ampicillin and amoxixillin-clavulanic acid, as well as a high rate of resistance to cephalosporins. A higher rate of resistance to tetracycline was observed in E. coli of cat origin compared with isolates of other sources. All the strains tested were sensitive to carbapenems.

In light of recent in vivo acquisitions, it might be reasonable to hypothesize a possible link between the occurrence of a high rate of resistance to tetracycline in humans and pets and the occurrence of tetracyclines in their sera [37-40]. Moreover, several reports demonstrated that even respecting withdrawal times in intensive farming, a huge amount of oxytetracycline could be recovered in the bone of the animals, in particular chickens [41], and then transferred to the pet food chain, which employs a chicken bone percentage ranging from $20 \%$ to $30 \%$ for kibble production [38,42-44]. Thus, the chronic intake of such food might account for the presence of tetracyclines' resistance in pets but also in humans, where the presence of chicken bone residues has been observed in Vienna sausages (data not shown).

The most frequent ESBL genes in humans and pet samples were $b l a_{\mathrm{CTX}-\mathrm{M}-1}$ and $b l a_{\mathrm{CTX}-\mathrm{M}-15 \text {, }}$ especially in E.coli strain, as reported by other authors $[15,45,46]$. In the past, bla $a_{\mathrm{CTX}-\mathrm{M}-15}$ was merely associated with strains of human origin [47], and CTX-M-1 was the major CTX-M sub-type in cattle, pigs, poultry, and companion animal isolates in Europe $[45,48,49]$. Actually, this close correspondence between CTX-M types and isolates of human or animal origin is no longer so obvious. An increasing number of studies identified blaCTX-M-1 and bla $a_{\mathrm{CTX}-\mathrm{M}-15}$ in both types of populations $[15,50]$, and our results confirm this trend. The resistance genes reported in this study are similar to those found in both humans and pet samples as reported elsewhere [15,50]. The survey of fimA, sfa, cnf1, papC, iutA, hlyA, and cdt genes circulation yielded results similar to those obtained in other studies [51-54]. The results provide evidence that two virulence factors (papC and hlyA) were present in all E. coli isolates; in fact, the association of hlyA with papC and sfa that was observed in the present research indicated that when hlyA is present in the genome, these other genes are present as well. This may be explained by the presence of a direct chromosomal linkage among these operons within particular DNA units on the chromosome, which are termed pathogenicity islands (PAIs) and carry virulence-associated genes coding sfa, hlyA, and papC [55,56]. The prevalence of virulence genes (cnf, hly, and pap) in humans here reported $(31.9 \%)$ was closely similar to the results from Usein et al. [57] on the frequency of these genes $(35,5 \%)$ in fecal $E$. coli isolated from healthy adult humans.

Various epidemiological studies suggest that animals can carry VRE in their intestinal microbiota and be the source of VRE infection in humans (according to a classical zoonotic cycle) [58-60]. In fact, these VRE strains of animal origin can determine the colonization of human gut expressing their pathogenicity by transferring their resistance genes to other human intestinal bacteria [61]. In our study, the highest percentages of resistance teicoplanin and vancomycin were detected only in cat isolates. Vancomycin is an antibiotic of last resort in the treatment of Gram-positive bacterial infections, including enterococcal infections. The emergence of vancomycin-resistant enterococcal strains and the risk of transmission of resistance genes to the susceptible bacteria pose a serious risk to public health. 


\section{Material and Methods}

\subsection{Study Design}

A total of 100 fecal samples, including 50 humans, coming from subjects of variable age (12-77 years) and sex (women and men), 25 dogs, and 25 cats were used in the study.

Every owner ( $>18$ years old) chosen for the study had only one dog or one cat. The samples were collected for one year (2017), and the human and dog/or cat participants had not been using antimicrobials for at least three months prior to the study. Bacterial strains were selected using a protocol for growth in selective media containing antibiotics. The protocol of this study was submitted to the Research Ethics Committee of HUAP/UFF (CAAE0146.0.258.000-09) and the Animal Ethics Committee of the NAL/UFF (NAL00126-09), and it was approved and certified by both committees.

\subsection{Isolation and Identification of Bacterial Strains}

Fecal samples on swabs from dogs/cats and humans were obtained and processed for testing.

After enrichment growth in Tryptic Soy Broth (TSB, bioMerieux, Florence, Italy) supplemented with $4 \mathrm{mg} / \mathrm{L}$ vancomycin and $2 \mathrm{mg} / \mathrm{L}$ cefotaxime for vancomycin-resistant enterococci (VRE) and Enterobacteriaceae ESBL/AmpC, respectively, samples were seeded onto Bile Esculin Azide agar plates (bioMerieux, Florence, Italy) for VRE isolation and onto MacConkey agar (bioMerieux, Florence, Italy) for Enterobacteriaceae isolation and incubated at $37^{\circ} \mathrm{C}$ for $24 \mathrm{~h}$. For both genera, two different colonies were isolated.

Colonies with typical enterococcal morphology were identified at the genus level by cultural characteristics, Gram staining, the catalase test, and the bile aesculin reaction. Species identification was confirmed by polymerase chain reaction (PCR) using primers and conditions for the different enterococcal species [62,63].

Additionally, colonies with typical Enterobacteriaceae morphology (four per sample) were selected and identified by classical biochemical methods (Gram staining, catalase, oxidase, indole, Methyl-Red-Voges-Proskauer, citrate, and urease), and by the API 20E system (bioMerieux, Florence, Italy).

The isolates were confirmed using Vitek-2 (bioMerieux, Florence, Italy).

\subsection{Antimicrobial Susceptibility Test}

Antibiotic susceptibility was determined by the broth microdilution method on Mueller Hinton broth (Scharlab, Milan, Italy) according to the Clinical Laboratory Standards Institute (CLSI) [64]. As for Enterococci, ampicillin, amoxicillin/clavulanate, streptomycin, erythromycin, tetracycline, ciprofloxacin, teicoplanin, vancomycin, and tigecycline were tested, while ampicillin, amoxicillin/clavulanate, ciprofloxacin, tetracycline, cefotaxime, ceftazidime, cefepime, imipenem, and meropenem were tested on Enterobacteriaceae.

The Enterococcus faecalis strain ATCC 29,212 and Escherichia coli ATCC 25,922 were included to validate the antimicrobial susceptibility results as recommended for quality control by the European Committee on Antimicrobial Susceptibility Testing (EUCAST) [65].

\subsection{Detection of Van Genes}

DNA was extracted from the samples using a standard heat lysis protocol [66] and two vancomycin resistance-associated genes, vanA and vanB, were detected by PCR using primers that were used in previous studies [62]. Then, amplicons were analyzed on 1\% agarose Tris-Borate-EDTA (TBE) gel containing GelRed ${ }^{\circledR}$ (Sigma, Milan, Italy). Following gel electrophoresis at $150 \mathrm{~V}$ for 3 to $5 \mathrm{~h}$, the images were recorded. 


\subsection{Detection and Sequencing of Extended Spectrum Lactamase and AmpC Genes}

Regarding the molecular tests, DNA was extracted using a standard heat lysis protocol [66]. For the detection of $b l a_{\mathrm{TEM}}, b l a_{\mathrm{SHV}}$, and bla $a_{\mathrm{CTX}-\mathrm{M}}$ genes, the multiplex-PCR described by Kim et al. was used [67]. Furthermore, primer sets described by Perez-Perez and Hanson [66] to detect AmpC products were used. PCR-positive amplicons were purified by the QIAquick PCR Purification Kit (Qiagen, Milan, Italy) and directly sequenced using amplification primers on the 3130 Genetic Analyzer (Applied Biosystems, Milan, Italy). Purification and sequencing were carried out by Genex CZ, s.r.o. Sequence alignment and analysis were performed online using the BLAST program of the National Center for Biotechnology Information (www.ncbi.nlm.nih.gov).

\subsection{Detection of Virulence Factors Cytolysin, Gelatinase, and Aggregation Substance (AS) Production in Enterococcus Species}

As reported by Gulhan et al., Brain Heart Infusion agar (bioMerieux, Florence, Italy), supplemented with $5 \%$ horse blood, was used for the detection of cytolysin activity, while gelatinase production was evaluated using Todd-Hewitt agar (bioMerieux, Florence, Italy), and the measurement of the AS of the enterococci was performed by clumping assay [51].

\subsection{Detection of Virulence Genes in Enterococcus Species by PCR}

PCR amplification was performed to detect the presence of genes involved in the expression of cytolysin (cylA, cylB, cylM), aggregation substance (agg), gelatinase (gelE), enterococcal surface protein (esp), and cell wall adhesins (efaAfs and efaAfm), using the primers described by Eaton and Gasson (2001) [68].

\subsection{Detection of Virulence Factors Cytolysin (Hemolysin) and Gelatinase Production in Enterobacteriaceae Species}

Cytolytic protein toxins (alpha hemolysin) produced by most hemolytic bacteria were assayed by culturing on $5 \%$ sheep blood agar at $37^{\circ} \mathrm{C}$ for $24 \mathrm{~h}$. Hemolysin production was detected by the presence of a complete heamolytic zone around the colony [69].

Gelatinase production was assayed by inoculating test organisms on Gelatin agar and incubated at $37^{\circ} \mathrm{C}$ for $24 \mathrm{~h}$; the culture was flooded with mercuric chloride solution; thus, the development of opacity in the medium and a zone of clearance around the bacterial colonies were considered positive factors for the presence of gelatinase [70].

\subsection{PCR detection of Virulence Genes of Enterobacteriaceae Species}

Virulence genes were also detected by PCR, using primers targeting 7 extraintestinal putative virulence factors, which included adhesion genes (afa, papC, and sfa), toxin genes (cdt, cnf1, and hlyA), and the aerobactin receptor gene (iutA) [52,71-74].

Statistical Analysis

A Chi-squared exact test was used to compare the prevalence of resistance to antimicrobials simultaneously assayed on E. faecium and E. faecalis of all species and on E. coli and C. freundii of pets. Coversely, Fisher's exact test was used to compare the prevalence of resistance to antimicrobials simultaneously assayed on E. coli, C. freundii, and K. pneumoniae of humans. All statistical analyses were performed with GraphPad Prism 8 (GraphPad Soft- ware Inc., San Diego, CA, USA). ${ }^{*} p<0.05$ was considered significant.

\section{Conclusions}

Pets usually live in close contact with their owners, and this suggests the hypothesis that these animals, besides livestock [17], chickens, and pigs [75], might become reservoirs of multiresistant 
strains, representing a source of infection and a pool of resistance genes trasferable by conjugation to human pathogens. More data, in particular on plasmids and host bacteria, are required to draw any conclusions on genetic relatedness and the possible transmission of these "superbugs" from pets to human and vice versa.

Author Contributions: Conceptualization, R.I., P.M. and C.S.; methodology, R.I. and C.S.; software, C.S.; validation, A.D.C., P.M. and C.S.; formal analysis, R.I., A.D.C., P.M. and C.S.; investigation, R.I. and C.S.; resources, C.S.; data curation, R.I., P.M. and C.S.; writing-original draft preparation, R.I., A.D.C., P.M. and C.S.; writing-review and editing, R.I., A.D.C., P.M. and C.S.; visualization, C.S.; supervision, P.M. and C.S.; project administration, P.M. and C.S.; funding acquisition, C.S. All authors have read and agreed to the published version of the manuscript.

Funding: This research received no external funding.

Conflicts of Interest: The authors declare no conflict of interest.

\section{References}

1. O'Neill, J. Tackling Drug-resistant Infections Globally: Final Report and Recommendations. 2016. Available online: https://amr-review.org/sites/default/files/160518_Final\%20paper_with\%20cover.pdf (accessed on 10 March 2020).

2. Hammerum, A.M. Enterococci of animal origin and their significance for public health. Clin. Microbiol. Infect. 2012, 18, 619-625. [CrossRef]

3. Suchodolski, J.S. Companion Animals Symposium: Microbes and gastrointestinal health of dogs and cats1. J. Anim. Sci. 2011, 89, 1520-1530. [CrossRef]

4. Lynch, S.V.; Pedersen, O. The Human Intestinal Microbiome in Health and Disease. New Engl. J. Med. 2016, 375, 2369-2379. [CrossRef] [PubMed]

5. Argudin, M.A.; Deplano, A.; Meghraoui, A.; Dodemont, M.; Heinrichs, A.; Denis, O.; Nonhoff, C.; Roisin, S. Bacteria from Animals as a Pool of Antimicrobial Resistance Genes. Antibiotics 2017, 6, 12. [CrossRef] [PubMed]

6. The European Centre for Disease Prevention and Control. Surveillance of Antimicrobial Resistance in Europe-Annual Report of the European Antimicrobial Resistance Surveillance Network (EARS-Net) 2018. Available online: https://www.ecdc.europa.eu/en/publications-data/surveillance-antimicrobial-resistanceeurope-2018 (accessed on 10 March 2020).

7. AL-Khafaji, J.K.T.; Samaan, S.F.; AL-Saeed, M.S. Virulence Factors of Enterococcus faecalis. Med. J. Babylon 2010, 7, 579-583.

8. Pillay, S.; Zishiri, O.T.; Adeleke, M.A. Prevalence of virulence genes in Enterococcus species isolated from companion animals and livestock. Onderstepoort J. Vet. Res. 2018, 85, e1-e8. [CrossRef]

9. Kiruthiga, A.; Padmavathy, K.; Shabana, P.; Naveenkumar, V.; Gnanadesikan, S.; Malaiyan, J. Improved detection of esp, hyl, asa1, gelE, cylA virulence genes among clinical isolates of Enterococci. BMC Res. Notes 2020, 13, 1-7. [CrossRef]

10. Ostholm-Balkhed, A.; Tarnberg, M.; Nilsson, M.; Nilsson, L.E.; Hanberger, H.; Hallgren, A.; Travel Study Group of Southeast Sweden. Travel-associated faecal colonization with ESBL-producing Enterobacteriaceae: Incidence and risk factors. J. Antimicrob. Chemother. 2013, 68, 2144-2153. [CrossRef]

11. Coque, T.M.; Baquero, F.; Canton, R. Increasing prevalence of ESBL-producing Enterobacteriaceae in Europe. Euro. Surveill. 2008, 13.

12. Wieler, L.H.; Ewers, C.; Guenther, S.; Walther, B.; Lubke-Becker, A. Methicillin-resistant staphylococci (MRS) and extended-spectrum beta-lactamases (ESBL)-producing Enterobacteriaceae in companion animals: Nosocomial infections as one reason for the rising prevalence of these potential zoonotic pathogens in clinical samples. Int. J. Med. Microbiol. 2011, 301, 635-641. [CrossRef]

13. Dutil, L.; Irwin, R.; Finley, R.; Ng, L.K.; Avery, B.; Boerlin, P.; Bourgault, A.M.; Cole, L.; Daignault, D.; Desruisseau, A.; et al. Ceftiofur resistance in Salmonella enterica serovar Heidelberg from chicken meat and humans, Canada. Emerg. Infect. Dis. 2010, 16, 48-54. [CrossRef] [PubMed]

14. EMA. Sales of Veterinary Antimicrobial Agents in 25 EU/EEA Countries in 2011. Available online: https: //www.ema.europa.eu/en/documents/report/sales-veterinary-antimicrobial-agents-25-european-union/ european-economic-area-countries-2011-third-european-surveillance-veterinary-antimicrobial_en.pdf (accessed on 10 March 2020). 
15. Schink, A.K.; Kadlec, K.; Schwarz, S. Analysis of bla(CTX-M)-carrying plasmids from Escherichia coli isolates collected in the BfT-GermVet study. Appl. Environ. Microbiol. 2011, 77, 7142-7146. [CrossRef] [PubMed]

16. Dierikx, C.M.; van Duijkeren, E.; Schoormans, A.H.; van Essen-Zandbergen, A.; Veldman, K.; Kant, A.; Huijsdens, X.W.; van der Zwaluw, K.; Wagenaar, J.A.; Mevius, D.J. Occurrence and characteristics of extended-spectrum-beta-lactamase- and AmpC-producing clinical isolates derived from companion animals and horses. J. Antimicrob. Chemother. 2012, 67, 1368-1374. [CrossRef] [PubMed]

17. Ewers, C.; Bethe, A.; Semmler, T.; Guenther, S.; Wieler, L.H. Extended-spectrum beta-lactamase-producing and AmpC-producing Escherichia coli from livestock and companion animals, and their putative impact on public health: A global perspective. Clin. Microbiol. Infect. 2012, 18, 646-655. [CrossRef] [PubMed]

18. Hamilton, E.; Kruger, J.M.; Schall, W.; Beal, M.; Manning, S.D.; Kaneene, J.B. Acquisition and persistence of antimicrobial-resistant bacteria isolated from dogs and cats admitted to a veterinary teaching hospital. J. Am. Vet. Med. Assoc. 2013, 243, 990-1000. [CrossRef]

19. Gandolfi-Decristophoris, P.; Petrini, O.; Ruggeri-Bernardi, N.; Schelling, E. Extended-spectrum beta-lactamase-producing Enterobacteriaceae in healthy companion animals living in nursing homes and in the community. Am. J. Infect. Control. 2013, 41, 831-835. [CrossRef]

20. Carvalho, A.C.; Barbosa, A.V.; Arais, L.R.; Ribeiro, P.F.; Carneiro, V.C.; Cerqueira, A.M. Resistance patterns, ESBL genes, and genetic relatedness of Escherichia coli from dogs and owners. Braz. J. Microbiol. 2016, 47, 150-158. [CrossRef]

21. Schouten, M.A.; Voss, A.; Hoogkamp-Korstanje, J.A. Antimicrobial susceptibility patterns of enterococci causing infections in Europe. The European VRE Study Group. Antimicrob. Agents Chemother. 1999, 43, 2542-2546. [CrossRef]

22. Murray, B.E. The life and times of the Enterococcus. Clin. Microbiol. Rev. 1990, 3, 46-65. [CrossRef]

23. Kataoka, Y.; Umino, Y.; Ochi, H.; Harada, K.; Sawada, T. Antimicrobial susceptibility of enterococcal species isolated from antibiotic-treated dogs and cats. J. Vet. Med. Sci. 2014, 76, 1399-1402. [CrossRef]

24. Rodrigues, J.; Poeta, P.; Martins, A.; Costa, D. The importance of pets as reservoirs of resistant Enterococcus strains, with special reference to vancomycin. J. Vet. Med. B Infect. Dis. Vet. Public Health 2002, 49, 278-280. [CrossRef] [PubMed]

25. Jackson, C.R.; Fedorka-Cray, P.J.; Davis, J.A.; Barrett, J.B.; Frye, J.G. Prevalence, species distribution and antimicrobial resistance of enterococci isolated from dogs and cats in the United States. J. Appl. Microbiol. 2009, 107, 1269-1278. [CrossRef] [PubMed]

26. Simjee, S.; White, D.G.; McDermott, P.F.; Wagner, D.D.; Zervos, M.J.; Donabedian, S.M.; English, L.L.; Hayes, J.R.; Walker, R.D. Characterization of Tn1546 in vancomycin-resistant Enterococcus faecium isolated from canine urinary tract infections: Evidence of gene exchange between human and animal enterococci. J. Clin. Microbiol. 2002, 40, 4659-4665. [CrossRef] [PubMed]

27. Leener, E.D.; Decostere, A.; De Graef, E.M.; Moyaert, H.; Haesebrouck, F. Presence and mechanism of antimicrobial resistance among enterococci from cats and dogs. Microb. Drug Resist. 2005, 11, 395-403. [CrossRef]

28. Ghosh, A.; Kukanich, K.; Brown, C.E.; Zurek, L. Resident Cats in Small Animal Veterinary Hospitals Carry Multi-Drug Resistant Enterococci and are Likely Involved in Cross-Contamination of the Hospital Environment. Front. Microbiol. 2012, 3, 62. [CrossRef]

29. Gulhan, T.; Boynukara, B.; Durmus, A.; Kiziroglu, I.; Sancak, Y.C. Enteric bacteria and some pathogenic properties of Enterococcus faecalis, Enterococcus faecium and Escherichia coli strains isolated from wild ducks and gulls. Fresen Environ. Bull. 2012, 21, 1961-1966.

30. Dupre, I.; Zanetti, S.; Schito, A.M.; Fadda, G.; Sechi, L.A. Incidence of virulence determinants in clinical Enterococcus faecium and Enterococcus faecalis isolates collected in Sardinia (Italy). J. Med. Microbiol. 2003, 52, 491-498. [CrossRef]

31. Iseppi, R.; Messi, P.; Anacarso, I.; Bondi, M.; Sabia, C.; Condo, C.; de Niederhausern, S. Antimicrobial resistance and virulence traits in Enterococcus strains isolated from dogs and cats. New Microbiol. 2015, 38, 369-378.

32. Hallgren, A.; Claesson, C.; Saeedi, B.; Monstein, H.J.; Hanberger, H.; Nilsson, L.E. Molecular detection of aggregation substance, enterococcal surface protein, and cytolysin genes and in vitro adhesion to urinary catheters of Enterococcus faecalis and E. faecium of clinical origin. Int. J. Med. Microbiol. 2009, 299, 323-332. [CrossRef] 
33. Upadhyaya, G.P.; Lingadevaru, U.B.; Lingegowda, R.K. Comparative study among clinical and commensal isolates of Enterococcus faecalis for presence of esp gene and biofilm production. J. Infect. Dev. Ctries. 2011, 5, 365-369. [CrossRef]

34. Tsikrikonis, G.; Maniatis, A.N.; Labrou, M.; Ntokou, E.; Michail, G.; Daponte, A.; Stathopoulos, C.; Tsakris, A.; Pournaras, S. Differences in biofilm formation and virulence factors between clinical and fecal enterococcal isolates of human and animal origin. Microb. Pathog. 2012, 52, 336-343. [CrossRef] [PubMed]

35. Lopez, M.; Tenorio, C.; Torres, C. Study of vancomycin resistance in faecal enterococci from healthy humans and dogs in Spain a decade after the avoparcin ban in Europe. Zoonoses Public Health 2013, 60, 160-167. [CrossRef] [PubMed]

36. Sharifi, Y.; Hasani, A.; Ghotaslou, R.; Naghili, B.; Aghazadeh, M.; Milani, M.; Bazmany, A. Virulence and antimicrobial resistance in enterococci isolated from urinary tract infections. Adv. Pharm. Bull. 2013, 3, 197-201. [CrossRef]

37. Di Cerbo, A.; Canello, S.; Guidetti, G.; Laurino, C.; Palmieri, B. Unusual antibiotic presence in gym trained subjects with food intolerance; a case report. Nutr. Hosp. 2014, 30, 395-398. [CrossRef] [PubMed]

38. Mazzeranghi, F.; Zanotti, C.; Di Cerbo, A.; Verstegen, J.P.; Cocco, R.; Guidetti, G.; Canello, S. Clinical efficacy of nutraceutical diet for cats with clinical signs of cutaneus adverse food reaction (CAFR). Pol. J. Vet. Sci. 2017, 20, 269-276. [CrossRef] [PubMed]

39. Di Cerbo, A.; Canello, S.; Guidetti, G.; Fiore, F.; Corsi, L.; Rubattu, N.; Testa, C.; Cocco, R. Adverse food reactions in dogs due to antibiotic residues in pet food: A preliminary study. Vet. Ital. 2018, 54, 137-146. [CrossRef]

40. Di Cerbo, A.; Guidetti, G.; Canello, S.; Cocco, R. A possible correlation between diet, serum oxytetracycline concentration and reproductive disturbances onset in bitches: Clinical observations and preliminary results. Turk. J. Vet. Anim. Sci. 2019, 43, 523-531. [CrossRef]

41. Palmieri, B.; Di Cerbo, A.; Laurino, C. Antibiotic treatments in zootechnology and effects induced on the food chain of domestic species and, comparatively, the human specie. Nutr. Hosp. 2014, 29, 1427-1433. [CrossRef]

42. Di Cerbo, A.; Palatucci, A.T.; Rubino, V.; Centenaro, S.; Giovazzino, A.; Fraccaroli, E.; Cortese, L.; Ruggiero, G.; Guidetti, G.; Canello, S.; et al. Toxicological Implications and Inflammatory Response in Human Lymphocytes Challenged with Oxytetracycline. J. Biochem. Mol. Toxicol. 2016, 30, 170-177. [CrossRef]

43. Odore, R.; De Marco, M.; Gasco, L.; Rotolo, L.; Meucci, V.; Palatucci, A.T.; Rubino, V.; Ruggiero, G.; Canello, S.; Guidetti, G.; et al. Cytotoxic effects of oxytetracycline residues in the bones of broiler chickens following therapeutic oral administration of a water formulation. Poult. Sci. 2015, 94, 1979-1985. [CrossRef]

44. Di Cerbo, A.; Scarano, A.; Pezzuto, F.; Guidetti, G.; Canello, S.; Pinetti, D.; Genovese, F.; Corsi, L. Oxytetracycline-Protein Complex: The Dark Side of Pet Food. Open Public Health J. 2018, 11, 162-169. [CrossRef]

45. Schmiedel, J.; Falgenhauer, L.; Domann, E.; Bauerfeind, R.; Prenger-Berninghoff, E.; Imirzalioglu, C.; Chakraborty, T. Multiresistant extended-spectrum beta-lactamase-producing Enterobacteriaceae from humans, companion animals and horses in central Hesse, Germany. BMC Microbiol. 2014, 14, 187. [CrossRef] [PubMed]

46. Hordijk, J.; Schoormans, A.; Kwakernaak, M.; Duim, B.; Broens, E.; Dierikx, C.; Mevius, D.; Wagenaar, J.A. High prevalence of fecal carriage of extended spectrum beta-lactamase/AmpC-producing Enterobacteriaceae in cats and dogs. Front. Microbiol. 2013, 4, 242. [CrossRef] [PubMed]

47. Livermore, D.M.; Hawkey, P.M. CTX-M: Changing the face of ESBLs in the UK. J. Antimicrob. Chemother. 2005, 56, 451-454. [CrossRef] [PubMed]

48. Overdevest, I.; Willemsen, I.; Rijnsburger, M.; Eustace, A.; Xu, L.; Hawkey, P.; Heck, M.; Savelkoul, P.; Vandenbroucke-Grauls, C.; van der Zwaluw, K.; et al. Extended-spectrum beta-lactamase genes of Escherichia coli in chicken meat and humans, The Netherlands. Emerg. Infect. Dis. 2011, 17, 1216-1222. [CrossRef] [PubMed]

49. Geser, N.; Stephan, R.; Hachler, H. Occurrence and characteristics of extended-spectrum beta-lactamase (ESBL) producing Enterobacteriaceae in food producing animals, minced meat and raw milk. BMC Vet. Res. 2012, 8, 21. [CrossRef]

50. Poirel, L.; Nordmann, P.; Ducroz, S.; Boulouis, H.J.; Arne, P.; Millemann, Y. Extended-spectrum beta-lactamase CTX-M-15-producing Klebsiella pneumoniae of sequence type ST274 in companion animals. Antimicrob. Agents Chemother. 2013, 57, 2372-2375. [CrossRef] 
51. Gulhan, T.; Aksakal, A.; Ekin, I.S.; Savasan, S.; Boynukara, B. Virulence Factors of Enterococcus faeciumandEnterococcus faecalisStrains Isolated from Humans and Pets. Turk. J. Vet. Anim. Sci. 2006, 30, 477-482.

52. Toth, I.; Herault, F.; Beutin, L.; Oswald, E. Production of cytolethal distending toxins by pathogenic Escherichia coli strains isolated from human and animal sources: Establishment of the existence of a new cdt variant (Type IV). J. Clin. Microbiol. 2003, 41, 4285-4291. [CrossRef]

53. Feria, C.; Machado, J.; Correia, J.D.; Goncalves, J.; Gaastra, W. Virulence genes and P fimbriae PapA subunit diversity in canine and feline uropathogenic Escherichia coli. Vet. Microbiol 2001, 82, 81-89. [CrossRef]

54. Tramuta, C.; Nucera, D.; Robino, P.; Salvarani, S.; Nebbia, P. Antibiotic Resistance Profiles in Relation to Virulence Factors and Phylogenetic Groups of Uropathogenic Escherichia coli Isolated from Dogs and Cats. In Veterinary Science: Current Aspects in Biology, Animal Pathology, Clinic and Food Hygiene; Pugliese, A., Gaiti, A., Boiti, C., Eds.; Springer Berlin Heidelberg: Berlin, Germany, 2012; pp. 51-55. [CrossRef]

55. Blum, G.; Falbo, V.; Caprioli, A.; Hacker, J. Gene clusters encoding the cytotoxic necrotizing factor type 1, Prs-fimbriae and alpha-hemolysin form the pathogenicity island II of the uropathogenic Escherichia coli strain J96. FEMS Microbiol. Lett. 1995, 126, 189-195. [CrossRef] [PubMed]

56. Hacker, J.; Kaper, J.B. The Concept of Pathogenicity Islands. In Pathogenicity Islands and Other Mobile Virulence Elements; ASM Press: Washington, DC, USA, 1999. [CrossRef]

57. Usein, C.R.; Damian, M.; Tatu-Chitoiu, D.; Capusa, C.; Fagaras, R.; Mircescu, G. Comparison of genomic profiles of Escherichia coli isolates from urinary tract infections. Roum. Arch. Microbiol. Immunol. 2003, 62, 137-154. [PubMed]

58. Cattoir, V.; Leclercq, R. Twenty-five years of shared life with vancomycin-resistant enterococci: Is it time to divorce? J. Antimicrob. Chemother. 2013, 68, 731-742. [CrossRef]

59. Dubin, K.; Pamer, E.G. Enterococci and Their Interactions with the Intestinal Microbiome. Microbiol. Spectr. 2014, 5. [CrossRef]

60. Herrero, I.A.; Fernandez-Garayzabal, J.F.; Moreno, M.A.; Dominguez, L. Dogs should be included in surveillance programs for vancomycin-resistant enterococci. J. Clin. Microbiol. 2004, 42, 1384-1385. [CrossRef]

61. Kataoka, Y.; Ito, C.; Kawashima, A.; Ishii, M.; Yamashiro, S.; Harada, K.; Ochi, H.; Sawada, T. Identification and antimicrobial susceptibility of enterococci isolated from dogs and cats subjected to differing antibiotic pressures. J. Vet. Med. Sci. 2013, 75, 749-753. [CrossRef]

62. Dutka-Malen, S.; Evers, S.; Courvalin, P. Detection of glycopeptide resistance genotypes and identification to the species level of clinically relevant enterococci by PCR. J. Clin. Microbiol. 1995, 33, 1434. [CrossRef]

63. Miele, A.; Bandera, M.; Goldstein, B.P. Use of primers selective for vancomycin resistance genes to determine van genotype in enterococci and to study gene organization in VanA isolates. Antimicrob. Agents Chemother. 1995, 39, 1772-1778. [CrossRef]

64. CLSI. Performance Standards for Antimicrobial Susceptibility Testing, 29th ed.; Clinical and Laboratory Standards Institute: Wayne, PA, USA, 2019; Volume 39.

65. EUCAST. Breakpoint Tables for Interpretation of MICs and Zone Diameters. Available online: http: //www.eucast.org/mic_distributions_and_ecoffs/(accessed on 10 March 2020).

66. Perez-Perez, F.J.; Hanson, N.D. Detection of plasmid-mediated AmpC beta-lactamase genes in clinical isolates by using multiplex PCR. J. Clin. Microbiol. 2002, 40, 2153-2162. [CrossRef]

67. Kim, J.; Jeon, S.; Rhie, H.; Lee, B.; Park, M.; Lee, H.; Lee, J.; Kim, S. Rapid Detection of Extended Spectrum beta-Lactamase (ESBL) for Enterobacteriaceae by use of a Multiplex PCR-based Method. Infect. Chemother. 2009, 41, 181-184. [CrossRef]

68. Eaton, T.J.; Gasson, M.J. Molecular screening of Enterococcus virulence determinants and potential for genetic exchange between food and medical isolates. Appl. Environ. Microbiol. 2001, 67, 1628-1635. [CrossRef] [PubMed]

69. Sharma, S.; Bhat, G.K.; Shenoy, S. Virulence factors and drug resistance in Escherichia coli isolated from extraintestinal infections. Indian J. Med. Microbiol. 2007, 25, 369-373. [CrossRef]

70. Derakhshandeh, A.; Eraghi, V.; Boroojeni, A.M.; Niaki, M.A.; Zare, S.; Naziri, Z. Virulence factors, antibiotic resistance genes and genetic relatedness of commensal Escherichia coli isolates from dogs and their owners. Microb. Pathog. 2018, 116, 241-245. [CrossRef] 
71. Le Bouguenec, C.; Archambaud, M.; Labigne, A. Rapid and specific detection of the pap, afa, and sfa adhesin-encoding operons in uropathogenic Escherichia coli strains by polymerase chain reaction. J. Clin. Microbiol. 1992, 30, 1189-1193. [CrossRef] [PubMed]

72. Pass, M.A.; Odedra, R.; Batt, R.M. Multiplex PCRs for identification of Escherichia coli virulence genes. J. Clin. Microbiol. 2000, 38, 2001-2004. [CrossRef] [PubMed]

73. Yamamoto, S.; Terai, A.; Yuri, K.; Kurazono, H.; Takeda, Y.; Yoshida, O. Detection of urovirulence factors in Escherichia coli by multiplex polymerase chain reaction. FEMS Immunol. Med. Microbiol. 1995, 12, 85-90. [CrossRef]

74. Moulin-Schouleur, M.; Schouler, C.; Tailliez, P.; Kao, M.R.; Bree, A.; Germon, P.; Oswald, E.; Mainil, J.; Blanco, M.; Blanco, J. Common virulence factors and genetic relationships between O18:K1:H7 Escherichia coli isolates of human and avian origin. J. Clin. Microbiol. 2006, 44, 3484-3492. [CrossRef]

75. de Jong, A.; Simjee, S.; Rose, M.; Moyaert, H.; El Garch, F.; Youala, M.; Group, E.S. Antimicrobial resistance monitoring in commensal enterococci from healthy cattle, pigs and chickens across Europe during 2004-14 (EASSA Study). J. Antimicrob. Chemother. 2019, 74, 921-930. [CrossRef] [PubMed]

(C) 2020 by the authors. Licensee MDPI, Basel, Switzerland. This article is an open access article distributed under the terms and conditions of the Creative Commons Attribution (CC BY) license (http://creativecommons.org/licenses/by/4.0/). 